\title{
Assessment of Women's Participation in Livestock Management Activities in Kanpur District, India
}

\author{
Aradhana Kushwaha*, Katayani Dipika Sachan and Rekha Dayal \\ Department of FRM, College of Home Science, C. S. Azad University of Agriculture \& \\ Technology, Kanpur, India \\ *Corresponding author
}

A B S T R A C T

\section{Keywords}

Assessment of Rural women, Role performance Livestock Management, Practices

Article Info

Accepted:

18 February 2019

Available Online:

10 March 2019
Livestock is a natural resource of good quality food, milk, meat, yogurt, butter, etc. Rural women actively participate in livestock management activities but their role is undervalued even though their social life is negatively affected. Thus the study focuses on performance Sanitation Activities by rural women in livestock management. The multipurpose random sampling technique was used and 180 respondents were taken from Sarsoul, Shivrajpur, and Choubeypur block Kanpur Nagar and Amaraudha, Malasha, Sarvankheda from Kanpur Dehat were randomly selected for the study. The results that Nearly seventy five percent respondents (74.44\% from Kanpur Nagar and $76.67 \%$ from Kanpur Dehat) 'always' 'clean cattle shed' followed by equal 58.89 percent respondents 'always' 'store dung cake' in Kanpur Nagar and 'prepare manure' in Kanpur Dehat respectively.

\section{Introduction}

All over the world the rural women participate in livestock management and are also involved in agricultural tasks. Women manage and care their animals in good way as compared with men. Women work more hardly in rural activities i.e. domestic, livestock and farming activities. Women have more importance as compared to men in livestock care and management. In the world, two-third of rural people and minority of sub-urban poor people depends on livestock for their livelihood. women spend most of the time in different activities such as processing of milk, making and collecting dung cake, cleaning of animals sheds, watering, bathing, making dung-pads and cleaning sheds and grazing animals (Nazli and Hamid, 2007).

They also perform difficult tasks like fodder chopping, fodder cutting, rearing, marketing, milking and treatment of animals. Therefore, rural women are involved in almost all livestock-related activities. But, their involvement in livestock-sector is considered as part of their housework and their role in livestock-sector is always undervalued. 


\section{Materials and Methods}

Uttar Pradesh was chosen as locale of the study. This was done with the intension that U.P. is a major state of the country and rural women have an important role to play in the development of the state as well as the country. This area was deliberately selected for this study as the researcher hailed from this place. U.P is divided into district Kanpur Nagar, and Kanpur Dehat comprising of 10 blocks each. Out of these 20 blocks, 3 blocks namely Sarsoul, Shivrajpur, Choubeypur were selected from Kanpur Nagar and 3 blocks namely Amaraudha, Malasha, Sarvankheda were randomly selected from Kanpur Dehat for the purpose of drawing samples. These six blocks provided sufficient number of villages from where indicated size of sample could be drawn. List of total villages falling in the blocks was prepared separately for each of the six blocks. From each of the six blocks two villages situated at a distance were selected with the help of systematic random sampling method. Thus, a total of 12 villages ( 2 from each block) were selected for the purpose of drawing the required sample of respondents. A group of 15 rural women was selected randomly from each listed village. Lists of rural women were prepared with the help of respective Village list. The selected rural women were categorized according to age groups. A total sample of 180 rural women was drawn for interviewing them personally. Socio-economic features of rural women included age, education, family structure, family size, annual income of livestock (Dairy) Rs., Occupation of head of the family, etc.

\section{Data collection}

The primary data was collected by the investigator herself personally, with the help of a well structured interview schedule. In all, 180 rural women were individually contacted and required information was gathered. Frequency, percentage, Weighted mean, Rank, Standard deviation (S.D.), Z-test, Correlation coefficient, were employed for statistical analysis.

\section{Results and Discussion}

\section{Selected Activities Performed by Rural Women Related to Livestock Management}

Often it is assumed that a household is a unit of production where all the members have the same objectives and interests. The husband and wife may have both shared and separate objectives and interest in dairy production and each one tries to work toward achieving them. This situation has a great influence of the overall livestock management. Women play a major role in livestock management they solely or with the help of other family member perform nearly all the tasks related to livestock specially they shoulder responsibilities like feeding animals, watering animals, collection of fuel, milking, cleaning of shade and animals etc.

Data pertinent to selected activities perform by women (respondents) in sanitation activities were given in table 1 revealed that Nearly seventy five percent respondents $(74.44 \%$ from Kanpur Nagar and $76.67 \%$ from Kanpur Dehat ) 'always' 'clean cattle shed' followed by equal 58.89 percent respondents 'always' 'store dung cake' in Kanpur Nagar and 'prepare manure' in Kanpur Dehat respectively. About seventy six percent respondents from Kanpur Nagar 'always' 'make dung cake', whereas 74.44 percent respondents from Kanpur Dehat 'always' perform the activity 'storage of dung cakes' and 81.11 percent respondents from Kanpur Dehat 'always' 'makes dung cakes'. Along with these 42.22 percent respondents from Kanpur Nagar and 13.33 percent respondents 'always' perform 'Disinfecting the cattle shed' 
followed by 38.89 percent from Kanpur Nagar 'always' perform 'preparation of manure'.

Majority seventy percent respondents from Kanpur Dehat 'never' 'disinfected the cattle shed' while 16.67 percent respondents 'sometimes' did with mean score 1.43.

Ho: There is no significant difference between women performing of sanitation activities of Kanpur Nagar /Kanpur Dehat.

Significant value of $\mathrm{z}$ at 5 percent level of significance indicates that there is significant difference for the activities like disinfecting the cattle shed, storage of dung cakes and preparation of manure performed by women of Kanpur Nagar/Kanpur Dehat. Thus the null hypothesis was rejected partially.

In table 2, more than fifty five percent respondents from Kanpur Nagar 'never' 'collected fodder for animal' and 'not cut and chopped' too. In contradiction majority 73.33 percent and 65.56 percent respondents from Kanpur Nagar 'always' 'feed and arrange drinking water respectively for animal. Forty three percent respondents 'never' collect fodder for animal feeding while 32.22 percent reported they 'always' perform this activity in Kanpur Dehat. Maximum 76.67 percent and 78.89 percent respondents from Kanpur Dehat 'always' feed animal and arrange water for drinking the animal respectively

Fifty percent of total respondents from Kanpur Dehat 'always' cut chop fodder followed by 36.67percent 'sometimes' perform this activity. $Z$ values are significant at $5 \%$ level of significance for fodder collection for animals and fodder cutting and chopping activities.

Ho: There is no significant difference between women performing of fodder activities of Kanpur Nagar /Kanpur Dehat. Significant valve of $\mathrm{z}$ at 5 percent level of significance indicates that there is a significant difference for the activities that fodder collection for animals and fodder cutting and chopping performed by women of Kanpur nager/Kanpur dehat. Thus the null hypothesis was partially rejected.

Table 3 shows that more than fifty one percent respondents from Kanpur Nagar 'always' perform milking activity whereas 37.78 percent respondents from Kanpur Dehat 'always' perform this activity followed by 24.44 percent respondents from Kanpur Dagar whereas twenty one percent reported performing milking activity 'sometimes'. Approximately twenty eight percent respondents from Kanpur Nagar 'Never 'perform milking activity but in case of Kanpur Dehat the percentage exactly increased by ten. About thirty eight percent respondents 'never' perform milking activity. As far as processing is concern a great portion i.e. 82.22 percent respondents 'always' process milk for home use, whereas in Kanpur Nagar 61.11 percent respondents reported that they 'always' 'process milk for home use' followed by 28.89 percent respondents from Kanpur Nagar reported 'sometimes, whereas 10.00 percent reported 'never' performed 'processing of milk for home use' activity, but in case of Kanpur Dehat none of the respondents reported 'never' while about eighteen percent reported 'sometimes' 'processed milk for home use'. Marketing is generally considered as male activity but in case of milk and milk product it is also female activity. More or less in both the district in 'selling of milk and milk products' female dominance was observed. More than forty seven percent respondents from Kanpur Dehat and 35.56 percent respondents from Kanpur Nagar 'always' sell milk and milk products was their responsibility followed by 40.00 percent from Kanpur Nagar and forty three percent from Kanpur Dehat reported 'sometimes' (Fig. 1). 
Table.1 Distribution of respondents on the basis of performance of sanitation activities of livestock management

\begin{tabular}{|c|c|c|c|c|c|c|c|c|c|c|c|c|}
\hline \multirow[t]{2}{*}{$\begin{array}{l}\text { S. } \\
\text { No. }\end{array}$} & \multirow[t]{2}{*}{$\begin{array}{l}\text { Sanitation } \\
\text { Activities }\end{array}$} & \multicolumn{5}{|c|}{$\begin{array}{l}\text { Kanpur Nagar } \\
\mathrm{n}=90\end{array}$} & \multicolumn{5}{|c|}{$\begin{array}{l}\text { Kanpur Dehat } \\
\text { n=90 }\end{array}$} & \multirow[t]{2}{*}{$\mathbf{Z}$} \\
\hline & & Always & Sometimes & Never & $\begin{array}{l}\text { Mean } \\
\text { Score }\end{array}$ & SD & Always & Sometimes & Never & $\begin{array}{l}\text { Mean } \\
\text { Score }\end{array}$ & SD & \\
\hline \multirow[t]{2}{*}{ (a) } & \multirow{2}{*}{$\begin{array}{l}\text { Cleaning of cattle } \\
\text { shed }\end{array}$} & 67 & 20 & 3 & \multirow[t]{2}{*}{2.71} & \multirow[t]{2}{*}{0.52} & 69 & 18 & 3 & \multirow[t]{2}{*}{2.73} & \multirow[t]{2}{*}{0.51} & \multirow[t]{2}{*}{0.288} \\
\hline & & $(74.44)$ & $(22.22)$ & $(3.33)$ & & & (76.67) & $(20.00)$ & (3.33) & & & \\
\hline \multirow[t]{2}{*}{ (b) } & \multirow{2}{*}{$\begin{array}{l}\text { Disinfecting the } \\
\text { cattle shed }\end{array}$} & 38 & 22 & 30 & \multirow[t]{2}{*}{2.09} & \multirow[t]{2}{*}{0.86} & 12 & 15 & 63 & \multirow[t]{2}{*}{1.43} & \multirow[t]{2}{*}{0.72} & \multirow[t]{2}{*}{$5.541^{*}$} \\
\hline & & $(42.22)$ & $(24.44)$ & $(33.33)$ & & & (13.33) & $(16.67)$ & $(70.00)$ & & & \\
\hline \multirow[t]{2}{*}{ (c) } & \multirow{2}{*}{$\begin{array}{l}\text { Storage of dung } \\
\text { cakes }\end{array}$} & 53 & 33 & 4 & \multirow[t]{2}{*}{2.54} & \multirow[t]{2}{*}{0.58} & 67 & 23 & 0 & \multirow[t]{2}{*}{2.74} & \multirow[t]{2}{*}{0.44} & \multirow[t]{2}{*}{$2.613^{*}$} \\
\hline & & $(58.89)$ & $(36.67)$ & $(4.44)$ & & & $(74.44)$ & $(25.56)$ & $(0.00)$ & & & \\
\hline \multirow[t]{2}{*}{ (d) } & \multirow[t]{2}{*}{ Making dung cakes } & 68 & 22 & 0 & \multirow[t]{2}{*}{2.76} & \multirow[t]{2}{*}{0.43} & 73 & 17 & 0 & \multirow[t]{2}{*}{2.81} & \multirow[t]{2}{*}{0.39} & \multirow[t]{2}{*}{0.907} \\
\hline & & $(75.56)$ & $(24.44)$ & $(0.00)$ & & & $(81.11)$ & (18.89) & $(0.00)$ & & & \\
\hline \multirow[t]{2}{*}{ (e) } & \multirow{2}{*}{$\begin{array}{l}\text { Preparation } \\
\text { manure }\end{array}$} & 35 & 40 & 15 & \multirow[t]{2}{*}{2.22} & \multirow[t]{2}{*}{0.71} & 53 & 34 & 3 & 2.56 & 0.56 & $3.493 *$ \\
\hline & & (38.89) & $(44.44)$ & (16.67) & & & $(58.89)$ & (37.78) & $(3.33)$ & & & \\
\hline
\end{tabular}


Table.2 Distribution of respondents on the basis of performance of fodder activities of livestock management

\begin{tabular}{|c|c|c|c|c|c|c|c|c|c|c|c|c|}
\hline \multirow[t]{2}{*}{ S No. } & \multirow[t]{2}{*}{ Fodder Activities } & \multicolumn{5}{|c|}{ Kanpur Nagar $n=90$} & \multicolumn{5}{|c|}{ Kanpur Dehat } & \multirow[t]{2}{*}{$\mathbf{Z}$} \\
\hline & & Always & Sometimes & Never & $\begin{array}{l}\text { Mean } \\
\text { Score }\end{array}$ & SD & Always & Sometimes & Never & $\begin{array}{l}\text { Mean } \\
\text { Score }\end{array}$ & SD & \\
\hline \multirow[t]{2}{*}{ (a) } & Fodder collection for & 18 & 22 & 50 & \multirow{2}{*}{1.64} & \multirow[t]{2}{*}{0.79} & 29 & 22 & 39 & \multirow{2}{*}{1.89} & \multirow[t]{2}{*}{0.86} & \multirow[t]{2}{*}{$1.980 *$} \\
\hline & animals & $(20.00)$ & $(24.44)$ & $(55.56)$ & & & $(32.22)$ & $(24.44)$ & $(43.33)$ & & & \\
\hline \multirow[t]{2}{*}{ (b) } & Fodder cutting & 23 & 17 & 50 & \multirow{2}{*}{1.70} & \multirow[t]{2}{*}{0.85} & 45 & 33 & 12 & \multirow{2}{*}{2.37} & \multirow[t]{2}{*}{0.71} & \multirow[t]{2}{*}{$5.726^{*}$} \\
\hline & chopping & $(25.56)$ & (18.89) & $(55.56)$ & & & $(50.00)$ & $(36.67)$ & (13.33) & & & \\
\hline \multirow[t]{2}{*}{ (c) } & Feeding animals & 66 & 19 & 5 & \multirow[t]{2}{*}{2.68} & \multirow[t]{2}{*}{0.57} & 69 & 17 & 4 & \multirow[t]{2}{*}{2.72} & \multirow[t]{2}{*}{0.54} & \multirow[t]{2}{*}{0.536} \\
\hline & & (73.33) & (21.11) & $(5.56)$ & & & $(76.67)$ & (18.89) & $(4.44)$ & & & \\
\hline \multirow[t]{2}{*}{ (d) } & Arranging drinking & 59 & 25 & 6 & \multirow[t]{2}{*}{2.59} & \multirow[t]{2}{*}{0.61} & 71 & 14 & 5 & \multirow[t]{2}{*}{2.73} & \multirow[t]{2}{*}{0.55} & \multirow[t]{2}{*}{1.659} \\
\hline & water for animals & $(65.56)$ & $(27.78)$ & $(6.67)$ & & & (78.89) & $(15.56)$ & $(5.56)$ & & & \\
\hline \multirow[t]{2}{*}{ (e) } & Taking the animal out & 6 & 4 & 80 & \multirow{2}{*}{1.18} & \multirow[t]{2}{*}{0.53} & 8 & 5 & 77 & \multirow{2}{*}{1.23} & \multirow[t]{2}{*}{0.60} & \multirow[t]{2}{*}{0.661} \\
\hline & for grazing & $(6.67)$ & $(4.44)$ & $(88.89)$ & & & $(8.89)$ & $(5.56)$ & $(85.56)$ & & & \\
\hline
\end{tabular}


Table.3 Distribution of respondents on the basis of performance of Milking activities of livestock management

\begin{tabular}{|c|c|c|c|c|c|c|c|c|c|c|c|c|}
\hline \multirow[t]{2}{*}{$\begin{array}{l}\text { S } \\
\text { No. }\end{array}$} & \multirow[t]{2}{*}{$\begin{array}{l}\text { Milking of animals } \\
\text { Activities }\end{array}$} & \multicolumn{5}{|c|}{$\begin{array}{l}\text { Kanpur Nagar } \\
n=90\end{array}$} & \multicolumn{5}{|c|}{$\begin{array}{l}\text { Kanpur Dehat } \\
\mathbf{n}=90\end{array}$} & \multirow[t]{2}{*}{$\mathbf{Z}$} \\
\hline & & Always & Sometimes & Never & $\begin{array}{l}\text { Mean } \\
\text { Score }\end{array}$ & SD & Always & Sometimes & Never & $\begin{array}{l}\text { Mean } \\
\text { Score }\end{array}$ & SD & \\
\hline \multirow[t]{2}{*}{ (a) } & \multirow[t]{2}{*}{ Milking of animals } & 46 & 19 & 25 & \multirow[t]{2}{*}{2.23} & \multirow[t]{2}{*}{0.86} & 34 & 22 & 34 & \multirow[t]{2}{*}{2.00} & \multirow[t]{2}{*}{0.87} & \multirow[t]{2}{*}{1.813} \\
\hline & & $(51.11)$ & $(21.11)$ & $(27.78)$ & & & $(37.78)$ & $(24.44)$ & $(37.78)$ & & & \\
\hline \multirow[t]{2}{*}{ (b) } & \multirow{2}{*}{$\begin{array}{l}\text { Processing of milk } \\
\text { for home use }\end{array}$} & 55 & 26 & 9 & \multirow[t]{2}{*}{2.51} & \multirow[t]{2}{*}{0.67} & 74 & 16 & 0 & \multirow[t]{2}{*}{2.82} & \multirow[t]{2}{*}{0.38} & \multirow[t]{2}{*}{$3.823 *$} \\
\hline & & $(61.11)$ & $(28.89)$ & $(10.00)$ & & & $(82.22)$ & $(17.78)$ & $(0.00)$ & & & \\
\hline \multirow[t]{2}{*}{ (c) } & \multirow{2}{*}{$\begin{array}{l}\text { Selling milk \& milk } \\
\text { products }\end{array}$} & 32 & 36 & 22 & \multirow[t]{2}{*}{2.11} & \multirow[t]{2}{*}{0.77} & 42 & 39 & 9 & \multirow[t]{2}{*}{2.37} & \multirow[t]{2}{*}{0.66} & \multirow[t]{2}{*}{$2.401 *$} \\
\hline & & $(35.56)$ & $(40.00)$ & $(24.44)$ & & & $(46.67)$ & $(43.33)$ & $(10.00)$ & & & \\
\hline
\end{tabular}

(Figures in parentheses denote percentage); *Significant at $5 \%$ level of significant at dt-88

Fig.1 Comparative participation of rural women in live stock management activities on the basis of mean score

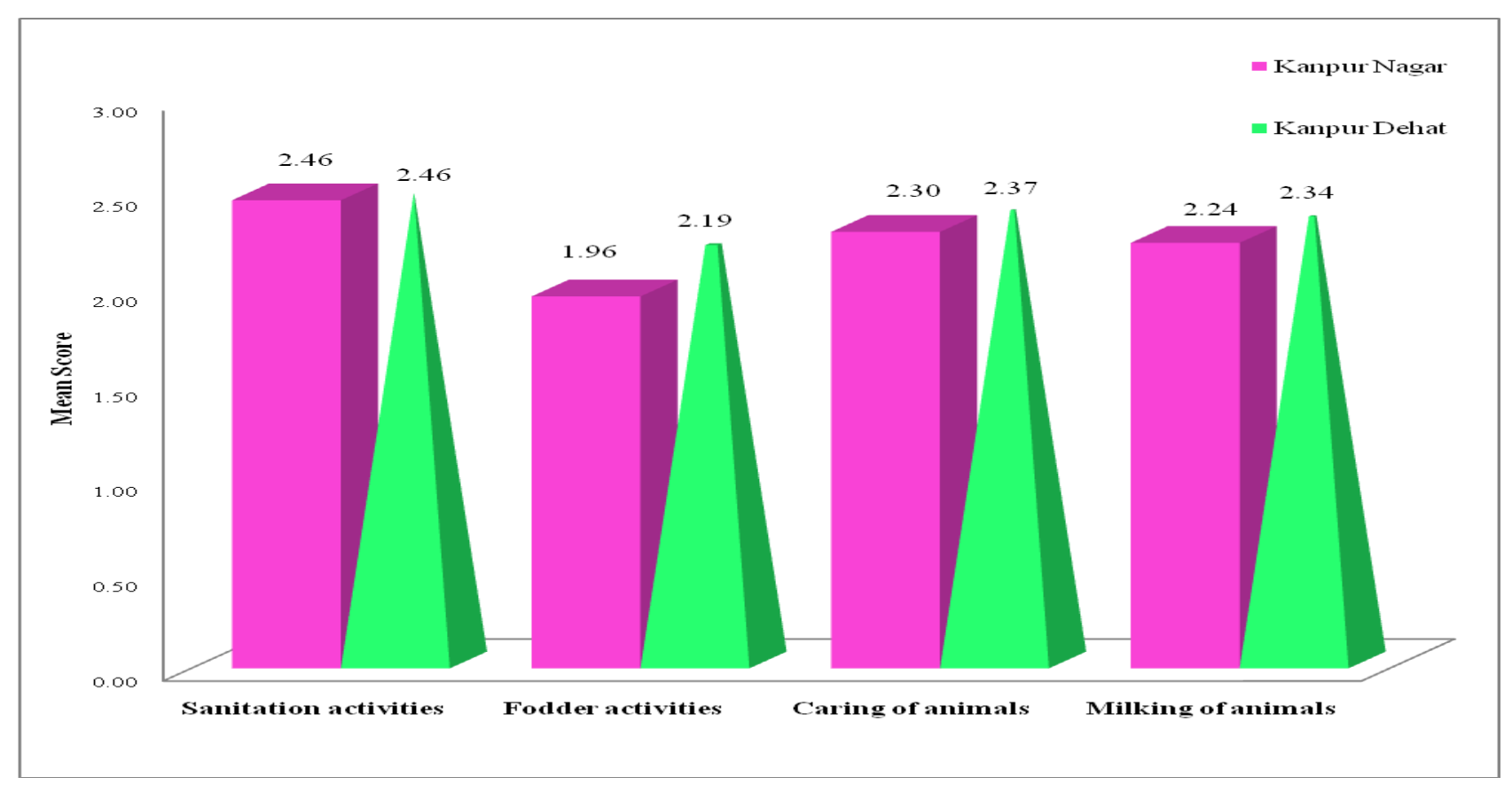


Only ten percent from Kanpur Dehat and twenty four percent from Kanpur Nagar reported they never, performed sell "milk and milk products activity'. Rathod et al., (2011) More than half of the women (58\%) participated independently or with support of the female $(30 \%)$ in processing of milk and milk products. A majority of them $(68 \%)$ also looked after the processed products at household level independently. But their participation in marketing related activities was less as compared to processing activities was 2.76. The reason behind low participation of women in marketing activities might be due to illiteracy, less mobility, male dominance and social mores and taboos prevalent in the society. Similar findings were revealed that a majority of farm women were involved in sale of milk and milk products and milk processing activities like butter preparation and ghee making.

Ho: There is no significant difference between women performing of milking activities of Kanpur Nagar /Kanpur Dehat.

Significant value of $\mathrm{z}$ at 5 percent level of significance indicates that there is a significant difference for the activities that processing of milk for home use and selling milk and milk products s partially rejected; whereas Non significant difference was found for the activities i.e. milking of animals thus the null hypothesis was partially accepted.

\section{Policy Implications of the study}

Suitable training programmes for the skill development of rural women on animal keeping may be organized so that their earning potential may be increased with the improved efficiency of the rural women. Their participation in such programmes is likely to bring forward the real and practical problems that need immediate attention of the policy makers.

To upgrade female skills and knowledge in poultry production and the processing of milk, they need to be exposed appropriate technological packages. Credit should be provided at government level to interested women who want to start small business industries.

\section{References}

Nazli, H. and S. Hamid. 2007-Role of gender and intra household dynamics in Pakistan. Islamabad, Pakistan Institute of Development Economics (PIDE), Govt. of Pakistan; pp: 1-35.

Rathod, P. K., Nikan, T. R., Landge, S., Vajreshwari, S. and Hatey, A. 2011. Participation of Rural Women in Dairy Farming in Karnataka. Indian Res. J. Ext. Edu., 11(2)

\section{How to cite this article:}

Aradhana Kushwaha, Katayani Dipika Sachan and Rekha Dayal. 2019. Assessment of Women's Participation in Livestock Management Activities in Kanpur District, India. Int.J.Curr.Microbiol.App.Sci. 8(03): 2199-2205. doi: https://doi.org/10.20546/ijcmas.2019.803.263 